\title{
COMPARISON OF GROWTH PERFORMANCE THROUGH DIFFERENT LEVELS OF SUPPLEMENTARY FEED IN FISH POLYCULTURE SYSTEM
}

\author{
NAZIA SULTANA ${ }^{1}$, MD. ABU SAYED JEWEL \\ AND MD. RASHEDUL KABIR MONDOL \\ Department of Fisheries, University of Rajshahi, Bangladesh
}

\begin{abstract}
An experiment was carried out to evaluate the growth performance of carp polyculture system supplemented with different levels of supplementary feed. To undertake this investigation, two earthen ponds were stocked with $25 \%$ Labeo rohita, $25 \%$ Catla catla, 20\% Labeo calbasu, 20\% Ctenopharyngodon idella and 10\% Hypopthalmichthys molitrix with a total stocking density of 10000/ha. The net fish production was found to be 2,166 and $3,874 \mathrm{~kg} / \mathrm{ha} / \mathrm{yr}$ in pond-01 and pond-02, respectively. The total cost of fish farming of pond-01 and pond-02 were 64,268 BDT and 88,568 BDT per ha. The total return of pond-01 and pond-02 were BDT 1,04,280 BDT and 1,69,250 BDT per ha. Net benefit from pond-01 and pond-02 was 40,312 BDT and 80,682 BDT respectively. Net profit margin of pond-01 and pond-02 was $62.73 \%$ and $91.10 \%$. And finally the benefit cost ratios (CBR) were found to be $0.62: 1$ and $0.91: 1$ in pond-01 and pond-02, respectively.
\end{abstract}

Key words: Carp polyculture, Supplementary feed, Cost-benefit ratio

\section{Introduction}

Aquaculture plays an important role in food production as well as creates an employment opportunities in the world. Bangladesh is blessed with water resources and aquaculture is one of the fast growing sectors in this country. Fishes serves as valuable ingredient to a healthy diet because of its easily digestible high protein and unsaturated fat contents. It is often recommended for heart patients by doctors, since it is an excellent source of Omega-3 fatty acid. Fish are also rich in vitamins (fat-soluble vitamins A, D and E, and water-soluble vitamins, B complex) and minerals (especially calcium, phosphorus, iron, selenium and iodine in marine fishes) (Choo and Williams 2003, Sandhu 2005, Razvi 2006, Salim 2006 and Yildrim 2008). Therefore, fish can provide an important source of nutrients, particularly for those whose diets are lacking these nutritional constituents (World Aquaculture 2010). The demand for fish as main protein source increases every year due to increase of population in the country. But scientists, fish farmers and fishers face various constraints and vulnerabilities as they are main triggers for technology generation, production enhancement and sustainable fisheries development. The basic principle of this polyculture system is that the fish species with different feeding habits

\footnotetext{
${ }^{1}$ Corresponding author: nazia1711@gmail.com
} 
are cultured together to increase productivity by a more efficient utilization of the ecological resources in the aquatic environment (Lutz 2003).

Supplementary feeding is a management protocol to enhance the fish production in a pond culture system within the shortest possible time. Supplementary feeding increases the carrying capacity of culture systems and can enhance fish production by manifold (Hepher 1975 and Devaraj et al. 1986). Supplementary feed is found to be a useful tool for providing nutrient components and energy required for better fish growth and production (Abdelghany et al. 2002). According to Azim et al. (2002), specific growth rate of major carps were higher in fertilized pond supplemented with supplemental feed than in control (fertilization alone). Use of supplementary feed is also recommended along with the organic manure and chemical fertilizers in order to get maximum fish production from limited water bodies within the shortest possible time (Mahboob et al. 1995). Ali et al. (2003) also observed prominent increment in weight gain, feed conversion ratio (FCR) and net production in major carps supplemented with supplementary feed at the rate of $6 \%$ of body weight. These feed can be utilized in different combinations to provide optimum source of dietary nutrients. Combination of fish meal, sesame oil cake and mustard oil cakes proved to be cost effective and significantly affect on the growth performance of fish (Stickney 2000). Keeping in view the significance of supplementary feeding, the present study was conducted to assess the growth performance of carps in semi-intensive culture system.

\section{Materials and Methods}

The experiment was carried out in two earthen ponds (pond-01 and pond-02), measuring 890 and $2200 \mathrm{~m}^{2}$, respectively, located at Sagar para of Boalia thana under Rajshahi district of Bangladesh. Before starting the experiment, all aquatic weeds and unwanted biota were removed. Aquatic weeds were removed manually and unwanted fish was removed by using Phostoxin tablet at the rate of 4-5 pieces/decimal in pond-01 and 6-7 piece/decimal in pond-02. Then agricultural lime (calcium carbonate, $\mathrm{CaCO}_{3}$ ) was applied at the rate of $230 \mathrm{~kg} / \mathrm{ha}$. After primary preparation, both ponds were fertilized with cowdung and triple super phosphate (TSP) at the rate of 1720 and $20 \mathrm{~kg} / \mathrm{ha}$, respectively. Each pond was stocked with $25 \%$ Labeo rohita (individual weight 5-6 g), 25\% Catla catla (6-7 g), 20\% Labeo calbasu (4-6 g), 20\% Ctenopharyngodon idella (4-5 g), 10\% Hypophthalmichthys molitrix (4-5 g) with a total stocking density 1000/ha. Both ponds were fertilized with above mentioned rate at 10 days intervals at. Two ponds were supplemented with mustard oil cake, rice bran, maize bran at the rate of $1.09 \mathrm{~kg} / \mathrm{ha}$ and $1.336 \mathrm{~kg} / \mathrm{ha}$, respectively for a period of six months as daily basis. After that period, fish were caught and measured in terms of body weight. 
Fish survival rate $(\mathrm{S})$ was calculated as the number of fish harvested as percentage of the number of fish stocked, $\mathrm{S}(\%)=($ Number of fish $/$ Number in stocked $) \times 100$

Fish yield $(\mathrm{kg} / \mathrm{ha} / \mathrm{month}) /$ Total production $=$ Fish biomass at harvest - Fish biomass at stock

Finally, fish were harvested and counted.

Economics of two ponds : An economic analysis of two ponds was performed on the basis of the expenditure incurred and the total estimated return from the sale price (BDT) of the harvested fish. At the end of the experiment, all fish were sold locally and the total return was estimated. The following factors were used to the economics of different treatments of two ponds.

Net benefit $($ Tk. $)=$ total return $($ sale $)-$ total cost (investment)

Net profit margin $(\%)=\frac{\text { Net benefit }}{\text { Total investment }} \times 100$

$\mathrm{CBR}=\frac{\text { Net benefit }}{\text { Total investment }}$

Data and statistical analyses were done by using Microsoft Excel-add-in-DDxl. All data were checked for homogeneity of variance.

\section{Results and Discussion}

Production : The initial average body weight, the average body weight at the time of harvest, net body weight gain, survival rate and total yield of Labeo rohita, Catla catla, Labeo calbasu, Ctenopharyngodon idella and Hypophthalmichthys molitrix of pond-01 and pond 02 are presented in Table 1 .

Table 1. Growth performance and survival rate of carps in pond-01 and pond-02.

\begin{tabular}{|c|c|c|c|c|c|c|}
\hline Ponds & Carp variety & $\begin{array}{l}\text { Initial average } \\
\text { Weight }(\mathrm{g})\end{array}$ & $\begin{array}{l}\text { Final average } \\
\text { Weight }(\mathrm{g})\end{array}$ & $\begin{array}{l}\text { Average } \\
\text { Weight (g) }\end{array}$ & $\begin{array}{l}\text { Survival } \\
\text { rate }(\%)\end{array}$ & $\begin{array}{l}\text { Total } \\
\text { Production } \\
\text { (kg/ha/yr) }\end{array}$ \\
\hline \multirow{5}{*}{ Pond-01 } & L. rohita & 5.5 & 400.6 & 395.1 & 96 & \multirow{5}{*}{1976} \\
\hline & C. catla & 6.5 & 550.7 & 544.2 & 96 & \\
\hline & L. calbasu & 5 & 360.8 & 355.8 & 95 & \\
\hline & C. idella & 4.5 & 500.6 & 496.1 & 95 & \\
\hline & H. molitrix & 4.5 & 380.2 & 375.7 & 94 & \\
\hline \multirow{5}{*}{ Pond-02 } & L. rohita & 5.5 & 600.8 & 595.3 & 97 & \multirow{5}{*}{2791} \\
\hline & C. catla & 6.5 & 800.7 & 793.8 & 98 & \\
\hline & L. calbasu & 5 & 550.6 & 545.6 & 97 & \\
\hline & C. idella & 4.5 & 700.5 & 696 & 94 & \\
\hline & H. molitrix & 4.5 & 650.2 & 654.7 & 93 & \\
\hline
\end{tabular}

Economics analysis: A simple economic analysis was performed to estimate the net profit (total returns from harvest - total cost of production) and cost benefit-ratio (CBR $=$ total benefit - total cost) from polyculture of carps of two ponds separately which is shown in Table 2. 
Table 2. Economics of two cultural ponds.

\begin{tabular}{lcc}
\hline & Pond & \\
Parameters & Pond-01 & Pond-02 \\
\hline Total cost (BDT/ha) & & 104158 \\
Total return (BDT/ha) & 61628 & 169250 \\
Net benefit (BDT/ha) & 118190 & 65092 \\
Net profit margin (\%) & 56562 & 62.494 \\
CBR & 91.779 & $1: 0.62$ \\
\hline
\end{tabular}

The result of the present study shows that net body weight of all fishes in pond-02 was higher than in pond-01. The use of supplementary feed caused a significant increased yield in pond-02. The net fish production in pond- 02 was found to be $3874 \mathrm{~kg} / \mathrm{ha} / \mathrm{yr}$ while it was $2166 \mathrm{~kg} / \mathrm{ha} / \mathrm{yr}$ in pond-01. So feed based on semi-intensive culture system gave 1.41 times greater fish production than the simple extensive one. The yield of this semiintensive polyculture system is similar to several production levels obtained in other semi-intensive polyculture in the South Asian region, e.g, Shahabuddin et al. (1994) obtained yields of $2000-3400 \mathrm{~kg} / \mathrm{ha} /$ year. The result found to be similar with pond- 02 . Mahboob et al. (1995) suggested that application of supplementary feed along with chemical fertilizers and organic manure is the best mean to obtain maximum production in fish culture practices from confined water bodies within the limited possible time in semi intensive culture system.

The production cost was higher in pond-02 but the highest net revenue was obtained from this pond. The feeding rate was relatively higher in pond- 02 that's why the total production might be higher than pond-01. However, the simple economic analysis showed that the cost benefit-ratio (CBR) was higher in pond-02. Net benefit in polyculture of carps ranged from Tk. 88,745 to 93,805/ha/10 months (Miah et al. 1993) which is found similar with pond-02. In another study cost-benefit ratio (CBR) revealed significantly higher ratio (1:0.69) where formulated feed was used with fertilizer (Samad et al. 2014).

A simple cost and return analysis were done on the basis of both cost and full cost to determine the profitability (Zaher and Mazid 1993). Use of higher level of inputs usually results in higher outputs, consequently higher investments produces higher gross and net return on per unit water body of ponds (Rahman 1995 and Biswas 1990). Higher net return from the pond fish production is influenced by the price of outputs and economic use of both material inputs and labor (Rahman 1995).

This study indicated that the higher level of supplementary feeding increased cost of polyculture system of carps but it is more profitable and economically feasible than application of lower rate of supplementary feeding. The enhanced production in second 
pond can be justified by the increase of supplementary feeding which contributes to increase fish yield and finally total aquaculture production. This research could be helpful for sustainable aquaculture with supplementary feeding in North West of Bangladesh as well as also other parts of the country.

\section{Acknowledgement}

The authors would like to thank the owner/s of these ponds for providing facilities and the Department of Fisheries, University of Rajshahi, Bangladesh for laboratory facilities.

\section{References}

Abdelghany, E. A and M. H. Ahmad. 2002. Effects of feeding rates on growth and production of Nile tilapia, common carp and silver carp polyculture in fertilized ponds. Aquacult. Res., 33: 415-423.

Ali, M. R., I. Ahmed, M. Ahmed and L. Sahar. 2003. Influence of different levels of supplementary feeding on the growth performance of major carps. Pakistan J. Biol. Sci., 6(9): 849-853.

Azim, M. E., M. C. J. Verde gem, M. M. Rahman, M. A. Wahab, A. A. van Dam and M. C. M. Beveridge. 2002. Evaluation of polyculture of Indian major carps in periphyton-based ponds. Aquacult. 213: 131-149.

Biswas, S. S. 1990. An economic analysis of pond fish culture of BARC in some selected areas of Mymensingh district. M.S. Thesis, Department of Agricultural Economics, Bangladesh Agricultural University, Mymensingh. 42-52 pp.

Choo, P. S. and M. J. Williams. 2003. Fisheries production in Asia: Its role in food security and nutrition. Naga, The WorldFish Centre Quarterly. 26(2): 11-16.

Devaraj, K. V., G. Y. Keshavappa, and J. K. Manissery. 1986. Growth of grass carp, Ctenopharyngodon idella (Val.), fed on two terrestrial fodder plants. Aquacult. Fish. Managem. 17: 123-128.

Hepher, B. 1975. Supplementary feeding in fish culture. Proc. of 9th Intl. Congr. of Nutr., Karger, Baselm, Mexico. 3: 183-198.

Lutz, G. C. 2003. Polyculture principles practices and promises. Aquaculture magazine (March/April). 29(2):34-39.

Mahboob, S., A. N. Sheri and M. Javed. 1995. Influence of fertilizers and artificial feed on the nitrogen incorporation efficiency of fish. Pakistan J. Zool. 27(4): 349-351.

Mazid, M. A., M. Zaher, N. N. Begum, M. Z. Ali and F. Nahar. 1997. Formulation of cost effective feeds from locally available ingredients for carp polyculture systems for increased production. Aquacult. 151:71-78

Miah, M. S., M. S. Uddin and M. S. Shah. 1993. Effects of supplementary feed in carps polyculture systems. Bangladesh J. Agril. Sci. 20(2): 359-364.

Nandeesha, M. C., S. S. De Silva and D. K. Murthy. 2001. Use of mixed feeding schedules in fish culture: performance of common carp, Cyprinus carpio L., on plant and animal protein based diets. Aquacult. Res., 26(3): 161-166.

Rahman M. A. 1995. Economics of pond fish production under different management system in Tangail district. M.S. Thesis, Department of Agricultural Economics, Bangladesh Agricultural University, Mymensingh. 43-49 pp.

Razvi, M. 2006. Lahore-absolutely fishy: Nutritional value. The Review, Dawn, 12-13 pp.

Salim, M. 2006. Role of fish as food to human nutrition. International conference on" Solving problems of Freshwater Fish Farming in Pakistan" November 27-28, UVAS, Lahore. 20 pp. 
Sahabuddin, M., M. S. Miah and M. S. Alam. 1994. Study of production optimization through polyculture of indigenous and exotic carp. Bangladesh J. Train. Dev. 7:67-72

Samad, M. A., S. Jasmine, M. M. Rahman, N. Jahan, M. S. Reza, M. I. Hossain, M. Y. Hossain and R. Mohammad. 2014. Effect of Feeds and Fertilizers on Growth and Survival Rate of Threatened Labeo bata Fry in Earthen Nursery Ponds. World J. Zool. 9 (4): 244-249.

Sandhu, G. S. 2005. A Textbook of Fish and Fisheries. Dominant Publishers and Distributors, New Delhi. 39-40 pp.

Stickney, R. R. 2000. Carp Culture. Encyclopedia of Aquaculture. John Wiley and Sons, 147-153 pp.

World Aquaculture. 2010. Contribution to food security. FAO Fisheries and Aquaculture Technical Paper No. 500/1, Rome, FAO. 105 pp.

Yildrim, O. 2008. Aquafeed industry in Turkey: its aqua feed projections towards the year 2015. Tur. J. Fish. Aqua. Sci., 8: 93-98.

Zaher, M. and M. A. Mazid. 1993. Aquafeeds and feeding strategies in Bangladesh. Proceedings of the FAO/AADCP Regional Expert Consultation on Farm-Made Aquafeeds, 14-18 December 1992, Bangkok, Thailand, 161-180 pp.

(Revised copy received on 28/9/2016) 